\title{
PELATIHAN BLENDED LEARNING PADA GURU SMA KATOLIK 1 KABANJAHE
}

\author{
Sanjaya Pinem ${ }^{1^{*}}$, Viktor Edison Hutagaol ${ }^{2}$ \\ ${ }^{1}$ Program Studi Teknik Informatika, Universitas Efarina \\ ${ }^{2}$ Program Studi Teknik Lingkungan, Universitas Efarina \\ email: pinemsanjaya@gmail.com
}

\begin{abstract}
Objectives of this Community Services are 1) give knowledge and practical experience to teacher of SMA Katolik 1 Kabanjahe focusing in blended learning model. 2) Teachers can use Moodle as e-learning technology. This services in systematic mode starts from the initial discussion with principal and teacher about blended learning, collect the results of the initial questionnaire, and then give an assignment to the teachers about issuing a course, managed quizzes and taking exam. The result shows that 1) Teacher in SMA Katolik 1 Kabanjahe have high enthusiasm to follow instruction given by instructor to learn about moodle. 2) As result teacher know how to operate elearning with moodle software start from register a course, and managed content in moodle.
\end{abstract}

Keywords: blended learning; moodle; teaching technology

\begin{abstract}
Abstrak: Tujuan Pengabdian kepada Masyarakat ini adalah 1) memperluas wawasan, pengetahuan dan pengalaman secara langsung tentang model pembelajaran blended learning untuk guru guru khususnya Guru SMA Katolik 1 Kabanjahe. 2) Guru - guru dapat menggunakan teknologi pembelajaran elearning moodle. Metode pelaksanaan dimulai secara terstruktur mulai dari diskusi awal tentang blended learning, mengambil hasil kuesioner awal, selanjutnya memberikan tugas mandiri kepada guru - guru. Pelaksanaan pengabdian kepada masyarakat ini diikuti oleh 12 guru di SMA Katolik 1 Kabanjahe, Kab. Karo. Sumatera Utara. Hasil dari pengabdian ini menunjukkan bahwa 1) Guru di SMA Katolik 1 Kabanjahe dapat mengetahui aplikasi moodle sebagai teknologi pembelajaran dengan model blended learning. 2) Guru di SMA Katolik 1 Kabanjahe mampu mengoperasikan moodle mulai dari mendaftarkan siswa, mengisi materi, memberi kuis, dan cara mengevaluasi hasil kerja siswa.
\end{abstract}

Kata kunci: blended learning; moodle; teknologi pembelajaran;

\section{PENDAHULUAN}

Teknologi Informasi yang terupdate dapa memberikan manfaat bagi dunia pendidikan dan harus dirancang secara baik dan terorganisir (Wijaya et al., 2016). Meskipun demikian, teknologi informasi harus disertai dengan pengetahuan pengguna yang baik sehingga teknologi informasi tersebut dapat memberikan dampak yang sangat menguntungkan bagi pihak - pihak yang menggunakannya. Salah satu media teknologi informasi adalah media komputer dengan mengunakan internet (GALANG MARHENDRA et al., 2015).Teknologi informasi juga mampu yang menjadi media 
pembelajaran memungkinkan peserta didik untuk belajarsecara mandiri tanpa harus hadirnya seorang guru sehingga memunculkan belajar dengan menggunakan elearning (Thomas \& Setiaji, 2014).

Kehadiran elearning sebagai salah satu media pembelajaran dalam jaringan (daring) memberikan tenaga baru bagi tenaga pendidik sebagai cara untuk memberikan materi kepada peserta didik. Suasana pembelajaran dengan menggunakan teknik dalam jaringan (daring) memaksa tenaga pendidik untuk membuat pembelajaran se-kreatif mungkin serta aktif dalam jaringan (daring) sehingga peserta didik antusias dalam mengikuti pembelajaran daring (Sari, 2015).

Salah satu jenis elearning adalah blended learning dan di SMA Katolik 1 Kabanjahe masih belum efektif, sehingga dibutuhkan rencana agar dapat meningkatkan hasil belajar peserta didik sehingga tujuan pembelajaran dapat tercapai. Hal tersebut dikuatkan dengan hasil kuesioner awal tentang pengetahuan awal guru - guru SMA Katolik 1 Kabanjahe seperti Gambar 1 dibawah ini.

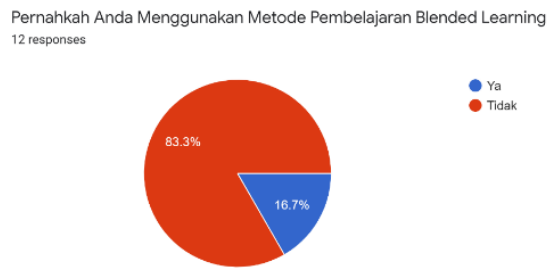

Gambar 1. Kuesioner Awal

Sebagai salah satu SMA unggul di Kota Kabanjahe dengan konektifitas internet yang sudah memadai karena berada di tengah kota sudah seharusnya pengetahuan guru - guru SMA Katolik 1 Kabanjahe akan media pembelajaran dalam jaringan (daring) mengetahui teknik dan cara menggunakan pembelajaran elearning dengan model blended learning (Batubara, 2017).Maka dari itu guru - guru SMA Katolik 1 Kabanjahe perlu metode pengajaran dengan menggunakan elearning model blended learning untuk meningkatan pengetahuan dan keterampilan guru - guru di sekolah tersebut sehingga pembelajaran kepada peserta didik dapat di optimalkan (Fauziah, 2011). Untuk mendukung tujuan dari metode ini maka dilakukan pelatihan guru - guru di SMA Katolik 1 Kabanjahe dalam menerapkan model blended learning sehingga mereka memiliki kemampuan dalam mengaplikasikan blended learning dalam pembelajaran secara maksimal (Nugraha et al., 2019). Pelatihan ini memungkinkan peserta pelatihan dapat menyerap ilmu pengetahuan secara optimal meskipun menggunakan media dalam jaringan (Sjukur, 2012).

\section{METODE}

Metode pemecahan masalah atas permasalahan tersebut di atas, diantaranya adalah dengan pelatihan model blended learning guru - guru di SMA Katolik 1 Kabanjahe, dapat diketahui tingkat kemampuan dan pemahaman guru - guru terhadapat teknik dan penggunaan blended learning dalam proses pembelajaran yang baik dan benar.

Metode pemecahan masalah pelatihan ini dapat diperinci sesuai dengan Tabel 1 berikut: 
Tabel 1. Metode Kegiatan Pelaksanaan Pengabdian

\begin{tabular}{lll}
\hline No & Materi & Metode Kegiatan \\
\hline 1 & Pengantar tentang sistem pembelajaran dengan & Ceramah, diskusi \\
& blended learning & \\
2 & Pemahaman blended learning & Ceramah, diskusi \\
3 & Kuisioner Awal & Tes Individu \\
4 & Install Moodle sebagai aplikasi Blended learning & Tutorial \\
5 & Manajemen Moodle sebagai Guru & Tutorial \\
6 & Review Materi & Tugas \\
7 & Tugas Mandiri: Pembuatan manajemen content pada & \\
& moodle termasuk pengaturan materi ajar dan & Tugas \\
& pengunggahan materi ajar & Diskusi, tanya jawab \\
8 & Pendampingan bagi yang memerlukan konsultasi \\
\hline
\end{tabular}

Acuan indikator keberhasilan dari

Evaluasi dalam pelatihan ini dilakukan dalam dua jenis yaitu yang pertama adalah Kuisioner Awal (Survey) yang diberikan kepada guruguru untuk mengetahui kemampuan sekarang sewaktu diadakan survey terutama untuk pengetahuan tentang blended learning dalam hal ini pengetahuan tentang moodle, atau blended learning secara umum. Dan yang kedua adalah Evaluasi Akhir (Post-test) yang dilakukan untuk mengetahui kemampuan guru - guru setelah dilakukan pelatihan blended learning. Evaluasi ini terbagi atas dua jenis yaitu dari sisi kemampuan guru untuk membuat materi ajar (course) dan melengkapinya, dan evaluasi tentang proses penyampaian materi atau isi dari moodle kepada peserta didik. pelatihan ini dilihat dari adanya pemahaman peserta tentang adanya model pembelajaran blended learning dengan menggunakan moodle. Dan yang kedua peserta pelatihan (guru - guru) memiliki pengetahuan tentang software pembelajaran terutama yang open source (sumber terbuka), dan terakhir guru - guru dapat melakukan manajemen moodle secara baik dan benar termasuk upload materi sesuai dengan mata pelajaran yang diampu yang efektif dan efisien.

\section{Faktor Pendukung Pelatihan}

Adanya faktor pendudukung dari pelatihan ini membuat pelatihan dapat berjalan dengan lancar yang diantaranya adalah lokasi Sekolah SMA Katolik 1 Kabanjahe dekat dengan kota, sehingga akses internet sudah cukup memadai untuk menggunakan teknologi pembelajaran dengan model blended learning. Serta motivasi para 
peserta dalam mengikuti pelatihan dari awal pelatihan hingga berakhirnya pelatihan didukung oleh pengetahuan dasar komputer yang cukup tinggi.

Faktor Penghambat Pelatihan

Faktor yang membuat pelatihan ini dapat menjadi kendala adalah kebanyakan guru belum mempunyai bahan ajar digital sehingga, materi yang dibuat harus dipersiapkan terlebih dahulu dan juga komputer dan laptop dalam tempat pelatihan sangat terbatas, sehingga workshop menggunakan alternative handphone pintar, dan pembagian komputer dan laptop digunakan oleh 2 atau 3 orang dalam 1 laptop. Dan tindak evaluasi dalam tugas mandiri, kecepatan guru - guru untuk menyelesaikan tugas mandiri tersebut bervariasi sehingga pendampingan pribadi memakan waktu yang cukup banyak, dan diperlukan pelatihan intensif bagi peserta pelatihan.

\section{PEMBAHASAN}

Secara garis besar pelatihan blended learning dengan pengembangan menggunakan moodle berlangsung lancar dan sangat baik, karena telah sesuai sesuai dengan rencana proposal yang telah ditetapkan terlebih dahulu. Dari jumlah total peserta pelatihan sebanyak 12 orang, tersebar dari beberapa pengampu mata pelajaran di SMA Katolik 1 Kabanjahe.

Tingkat kehadiran peserta pelatihan selama dua hari juga menunjukkan hasil yang cukup bagus karena 98\% dari peserta hadir dan mengikuti pelatihan setiap harinya. Dan didalam proses pelatihan ini, setiap peserta dapat mengakses moodle di server yang sudah disediakan panitia setelah diberikan pengarahan dan tata cara penginstallan moodle di komputer guru. Sehingga guru - guru peserta pelatihan dapat belajar sambil praktek langsung (learning by doing). Penyampaian materi diberikan kepada peserta pelatihan dengan menggunakan cara diskusi dan ceramah dan diberikan tutorial step by step.

Pada tahap evaluasi diberlakukan tugas mandiri yang diberikan kepada guru - guru untuk membuat konten elearning mereka sendiri didalam sistem moodle yang sesuai dengan mata pelajaran diampu di SMA Katolik 1 Kabanjahe. Proses belajar sendiri/mandiri, peserta pelatihan dibantu oleh panitia untuk memaksimalkan potensi guru dalam penggunaan model pembelajaran model blended learning, sehingga dalam akhirnya kemampuan guru untuk menyelesaikan tugas mandiri ini akan menjadi acuan apakah peserta sudah mempunyai kompetensi atau kemampuan yang diajarkan saat pelatihan.

Dari hasil yang didapatkan dari tugas mandiri guru - guru SMA Katolik 1 Kabanjahe, semuanya menyelesaikannya dengan baik. Waktu untuk menyelesaikan tugas mandiri bervariasi, ada yang cepat dan ada pula yang relatif lama

Kegiatan pelatihan dalam kegiatan pengabdian masyarakat ini dideskripsikan dalam tiga poin penting, yang pertama adanya kegiatan diskusi awal dan persiapan pelaksanan pengabdian yang berupa kegiatan kunjungan ke sekolah mitra untuk membicarakan beberapa hal teknis terkait pelaksanaan pelatihan blended learning dengan moodle bagi guru SMA KATOLIK 1 Kabanjahe serta penerapannya. 


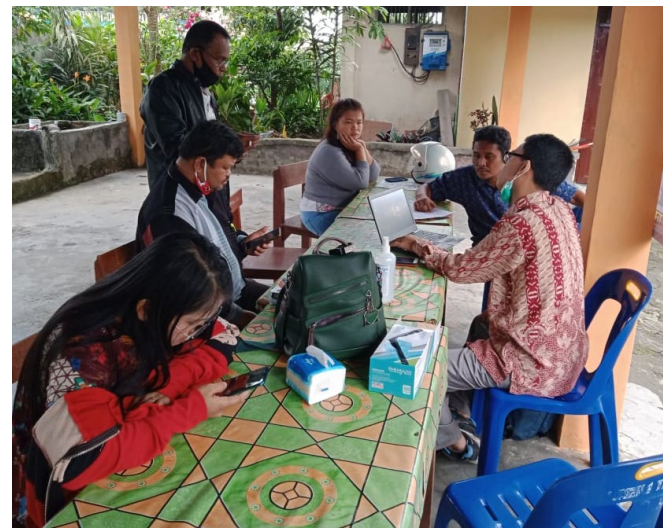

Gambar 2. Diskusi pelatihan dasar blended learning

Dan yang kedua inti dari pelatihan ini yaitu, prakek langsung model pembelajaran blended learning dengan moodle dengan untuk memberikan pengenalan kepada mitra guru-guru mengenai manfaat dan kelebihan blended learning untuk meningkatkan kompetensi guru sehingga pengetahuan guru akan perkembangan teknologi informasi khususnya dibidang Pendidikan dapat lebih meningkat.

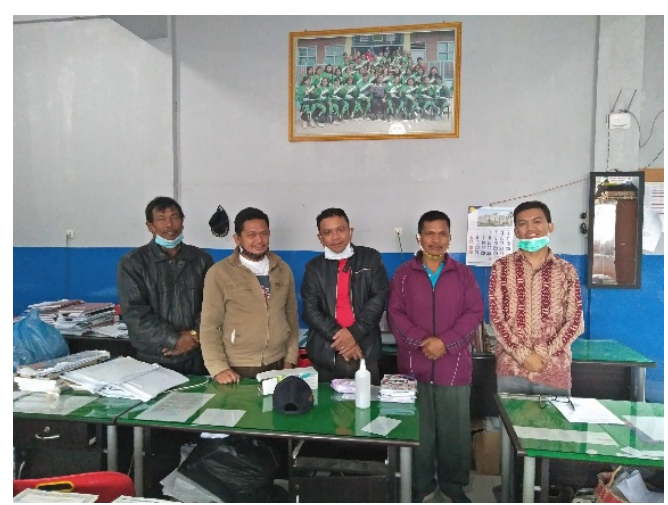

Gambar 2. Berfoto bersama setelah selesai pelatihan

Dan poin yang terakhir adalah pembangunan dan instalasi webserver xampp sebagai server moodle sebagai wadah untuk software moodle bekerja, sehingga peserta pelatihan dapat menerapkan ilmu yang didapat dari pelatihan ini secara langsung.

\section{SIMPULAN}

Simpulan pelaksanaan pengabdian ini adalah 1) Peserta pelatihan adalah guru-guru SMA Katolik 1 Kabanjahe, Kabupaten Karo berjumlah 12 orang. 2) Prosentase kehadiran peserta pelatihan hampir mencapai 99\% sehingga menunjukkan antusiasme guru - guru dalam mengikuti pelatihan model pembelajaran blended learning khususnya dalam hal memasukkan materi kedalam moodle serta manajemen kontek elearning. 3) Hasil evaluasi yang berupa tugas mandiri, guru - guru dapat menyelesaikan hasil yang baik, meskipun dalam proses pengerjaan yang bervariasi karena setiap guru untuk menyelesaikan tugas tersebut berbeda - beda.

\section{UCAPAN TERIMA KASIH}

Panitia pelaksana pelatihan dengan judul "PELATIHAN BLENDED LEARNING PADA GURU SMA KATOLIK 1 KABANJAHE" menyampaikan terimakasih kepada Kepala Sekolah SMA Katolik 1 Kabanjahe yang telah memberikan kesempatan kepada panitia untuk melaksanakan pengabdian ini.

\section{DAFTAR PUSTAKA}

Batubara, H. H. (2017). Pengembangan Situs e-Learning dengan Moodle versi 3.1 sebagai Media Pembelajaran pada Program Studi Pendidikan Guru Madrasah Ibtidaiyah. 
Al-Bidayah: Jurnal Pendidikan Dasar Islam, 9(1), 1-10.

Fauziah, Y. N. (2011). Analisis kemampuan guru dalam mengembangkan keterampilan berpikir kreatif siswa Sekolah Dasar kelas V pada pembelajaran Ilmu Pengetahuan Alam. Jurnal Edisi Khusus, 1(1), 98 106.

GALANG MARHENDRA, A.,

Wahyuni Suryaningtiyas, S., \& Kristanti, F. (2015).

PENGGUNAAN MODEL

PEMBELAJARAN BLENDED

LEARNING DALAM PEMBELAJARAN MATEMATIKA

KELAS VIII DI SMPN 38 SU$R A B A Y A$ [PhD Thesis]. Universitas Muhammadiyah Surabaya.

Nugraha, N. B., Sellyana, A., \& Suhaidi, M. (2019). PELATIHAN E-LEARNING PADA GURU SMA IT PLUS
BAZMA BRILLIANT. JURDIMAS ROYAL, 2(2), 127-132.

Sjukur, S. B. (2012). Pengaruh blended learning terhadap motivasi belajar dan hasil belajar siswa di tingkat SMK. Jurnal Pendidikan Vokasi, 2(3).

Thomas, P., \& Setiaji, K. (2014). Elearning dengan pendekatan kooperatif tipe jigsaw untuk meningkatkan aktivitas dan hasil belajar mahasiswa. Dinamika Pendidikan, 9(1).

Wijaya, E. Y., Sudjimat, D. A., \& Nyoto, A. (2016). Transformasi Pendidikan Abad 21 Sebagai Tuntutan Pengembangan Sumber Daya Manusia di Era Global. Prosiding Seminar Nasional Pendidikan Matematika. 